\title{
Study on Several Kinds of Polymer Emulsion Modified Cement Mortar Performance
}

\author{
Zheng $\mathrm{Li}^{1, \mathrm{a}}$, Hua Ou ${ }^{2, \mathrm{~b}}$, Xiao Chen ${ }^{1, \mathrm{c}}$, Jiqing Shi ${ }^{1, \mathrm{~d}}$, Lingli Peng ${ }^{1, \mathrm{e}}$, Hewen Chen ${ }^{3, \mathrm{f}}$ \\ ${ }^{1}$ Wuhan University of Technology \\ ${ }^{2}$ Hubei Safety \& Environment Technology Institute Co., Ltd. \\ ${ }^{3}$ EXi Expressway Administration of Hubei Department of Transportation

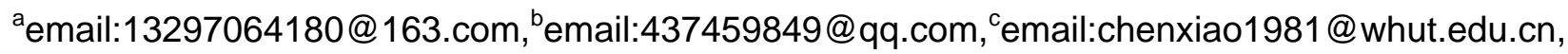 \\ demail:562644418@qq.com, ${ }^{\mathrm{e} e m a i l: 341850463 @ q q . c o m,{ }^{\mathrm{f}} \mathrm{email}: 19637943 @ q q . c o m}$
}

Keywords:Polymer cement mortar, Performance study

Abstract. Cement mortar is typical of a brittle material, with high compressive strength, low tensile strength, flexural strength, and bonding strength. This paper introduces that several polymer emulsions modified cement mortar. By researching the water-reducing, impermeability and mechanical properties of cement mortar, the results shows SD623 (Styrene-butadiene rubber latex) is most obvious.

\section{Introduction}

Cement mortar is typical of a brittle material, with high compressive strength, low tensile strength, flexural strength, and bonding strength[1]. It is difficult to meet the engineering requirements of durability and construction efficiency, greatly limits its application in construction engineering[2].

Today, polymer emulsion modified cement mortar is very hot, and the factors of affecting the modified cement mortar properties and in addition to the kind and performance of cement mortar , the main types , dosage ,curing methods of polymer mortar[3] . In this paper, several polymer modified cement mortar, so study its relative performance.

\section{Raw Materials and Test Method}

\section{Raw materials}

PO 42.5 cement using ordinary portland cement, meeting the relevant standards,Its chemical composition and physical properties are shown in table1,table2;

Shanghai styrene-butadiene latex (SD623) produced by BASF, Acronal styrene-acrylic emulsion(PS608), acrylic emulsion(S400),their Related properties are shown in table 3.

\begin{tabular}{cccccccc}
\hline \multicolumn{8}{c}{ Table1 The chemical composition of cement } \\
\hline compositio (\%) & $\mathrm{MgO}$ & $\mathrm{Al}_{2} \mathrm{O}_{3}$ & $\mathrm{SiO}_{2}$ & $\mathrm{SO}_{3}$ & $\mathrm{CaO}$ & $\mathrm{Fe}_{2} \mathrm{O}_{3}$ & Loss \\
content & 2.87 & 6.23 & 22.86 & 1.95 & 58.43 & 3.36 & 4.30 \\
\hline
\end{tabular}




\begin{tabular}{|c|c|c|c|c|c|c|c|c|c|c|c|}
\hline \multicolumn{12}{|c|}{ Table2 The physical properties of cement } \\
\hline \multirow{2}{*}{$\begin{array}{l}\text { perform } \\
\text { ance } \\
\text { density } \\
\text { (g/cm } \\
3)\end{array}$} & \multirow{2}{*}{$\begin{array}{l}\text { finene } \\
\mathrm{ss}(\%)\end{array}$} & \multirow{2}{*}{$\begin{array}{c}\text { norma } \\
\text { l consi } \\
\text { stency } \\
(\%)\end{array}$} & \multicolumn{2}{|c|}{$\begin{array}{l}\text { setting time } \\
\quad(\min )\end{array}$} & \multirow{2}{*}{$\begin{array}{l}\text { sta } \\
\text { bili } \\
\text { ty }\end{array}$} & \multicolumn{3}{|c|}{$\begin{array}{l}\text { breaking strengt } \\
\text { h (MPa) }\end{array}$} & \multicolumn{3}{|c|}{$\begin{array}{c}\text { compressive strength ( } \mathrm{M} \\
\mathrm{Pa})\end{array}$} \\
\hline & & & $\begin{array}{c}\text { initial } \\
\text { set }\end{array}$ & $\begin{array}{c}\text { final } \\
\text { set }\end{array}$ & & $3 d$ & $7 d$ & $28 d$ & 3d & 7d & $28 d$ \\
\hline 3.10 & 1.25 & 27.4 & 130 & 195 & $\begin{array}{c}\text { Co } \\
\text { nfo } \\
\text { rmi } \\
\text { ty }\end{array}$ & 6.5 & 8.2 & 10.4 & 26.8 & 41.7 & 54.3 \\
\hline
\end{tabular}

\begin{tabular}{clcc}
\hline \multicolumn{4}{c}{ Table 3 Polymer emulsion physical properties } \\
\hline The emulsion type & main chemical compositions & solid content (\%) & PH value \\
SD623 & styrene, PSB & 51 & $7.8-10$ \\
PS608 & crylic acid, styrol copolymer & 50 & $8.0-9.0$ \\
S400 & styrene, acrylics copolymer & 57 & $7.0-8.5$ \\
\hline
\end{tabular}

\section{Test Method}

Determination of the strength of cement mortar on the basis of national standards of GB/T1767

1-1999; Testing cement mortar fluidity is reference to national standard of GB-T2419 [4];

Permeability resistance is the basic guarantee of cement concrete has excellent durability. Due to the high testing precision, simple operation and time-consuming short (6 h),chloride ion permeability resistance index can be used as the main index of cement concrete durability test. So for PS608, SD623, S400, the three kinds of emulsion performance of the cement mortar, adopting the rapid determination of chloride ion diffusion coefficient method (RCM method) test, cement mortar impermeability is reference to national standards of JGJ 70-90 test[5].

\section{Experiments and Results}

\section{Polymer Emulsion on Cement water-reducing}

The selected gray sand ratio is 1: 3, polymer - cement ratio controlled as follows: $5 \%, 10 \%, 15 \%, 20 \%$, jump table fluidity of fresh mortar controlled as $150 \pm 5 \mathrm{~mm}$ and the water-cement ratio is adjusted according to the fluidity.

The water-reducing effect of these three kinds of different content of the emulsion, as shown in Fig.1. It can been seen that different type and different amount of the polymer emulsion have different effect of water-reducing: (1)At the same rate of polymer-cement, the order of water-reducing effect as follows: SD623 $>$ PS608 $>$ S400, the water-reducing of S400 is $13.1 \%$ when the polymer - cement ratio is $10 \%$, whereas the water-reducing rate of SD623 is $28.3 \%$ which is 2.2 times the S400; (2) With the increasing of the amount of polymer emulsion, water-reducing rate will increase, but when the polymer - cement ratio is higher than $15 \%$, the increasing trend of water-reducing by the polymer is not significantly increased. As PS608: the water-reducing rate increases at $42.9 \%$ when the cement ratio changes from $10 \%$ to $15 \%$, whereas the water-reducing rate increases at $6.7 \%$ when the cement ratio changes from 15\% to 20\%. It can been found that the effect of SD623 to reduce the water is best, whereas S400 is worst, and taking into account the cost-effective and polymer - cement ratio are no higher than 15 percent as much as possible. 


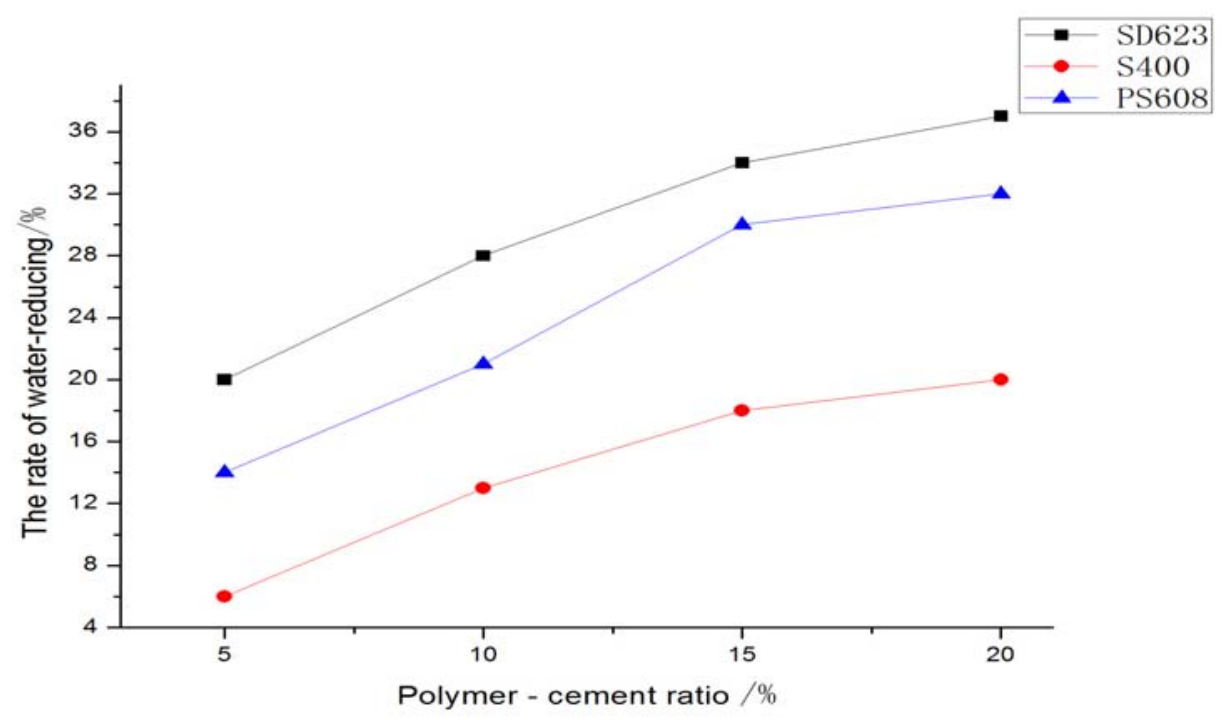

Fig.1 The effect of water-reducing of content among different types of polymer emulsion

\section{Impermeability of polymer-modified cement mortar}

The effect of PS608, SD623 and S400 on cement mortar impermeability is shown in Fig.2. It shows: Adding different types and different contents of polymer emulsion can reduce permeability coefficient of the cement mortar chloride, the orders of three kinds of latex modified mortar impermeability are SD623 $>$ PS608 $>$ S400. With the increasing of polymer - cement ratio, its impermeability increases. When the polymer - cement ratio is $20 \%$, modified mortar Chlorine ion permeability coefficient of SD623, PS608 and S400 are $3.4 \times 10^{-13} \mathrm{~m}^{2} / \mathrm{s}, 4.1 \times 10^{-13} \mathrm{~m}^{2} / \mathrm{s}$ and $5.2 \times 10^{-13} \mathrm{~m}^{2} / \mathrm{s}$, lower than the blank sample at $71.7 \%, 65.8 \%, 56.7 \%$, respectively. It shows that polymer emulsion can better improve the barrier properties of cement mortar.

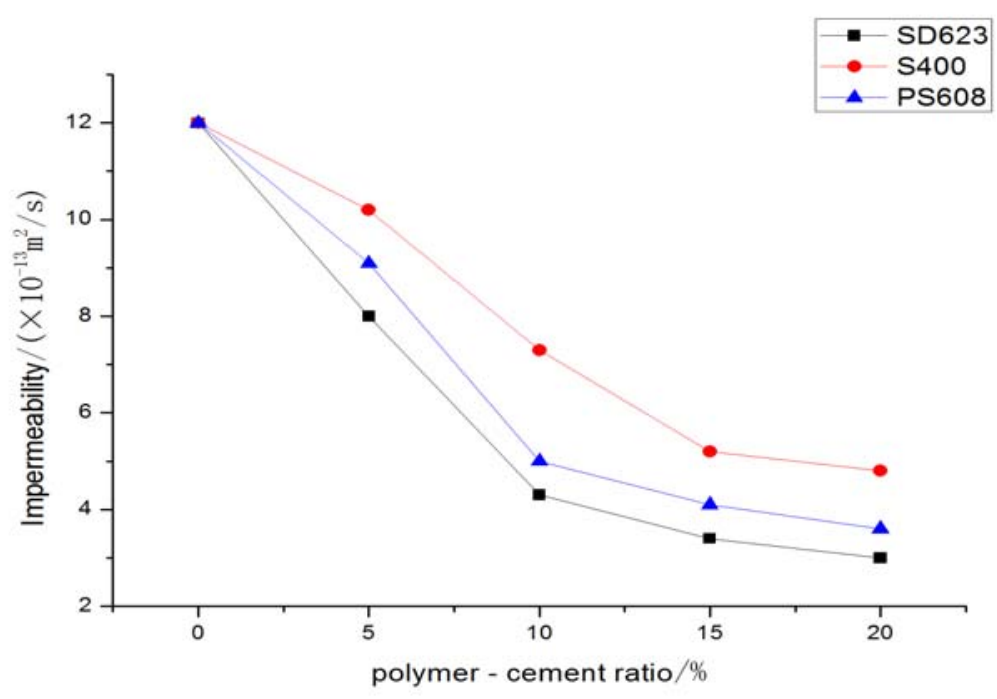

Fig.2 Effects of different types and content of the polymer emulsion on cement mortar impermeability

\section{Study of properties of polymer emulsion modified cement mortar}

The test results about how the type and amount of polymer emulsion affect the mechanical properties of mortar are shown in Table 1. It shows as follows:

Adding the polymer emulsion can better improve the ratio of bending-compressive strength, thereby increasing its flexibility, and the orders of the effect are: SD623 $>$ S400 $>$ PS608, in addition, 
each mixing ratio of cement mortar $7 \mathrm{~d}$ fold compression ratio is significantly higher than $28 \mathrm{~d}$ fold compression ratios.

\begin{tabular}{|c|c|c|c|c|c|c|c|}
\hline Types & $\mathrm{P} / \mathrm{C}$ & & $3 \mathrm{~d}$ & & & $28 d$ & \\
\hline \multirow[b]{2}{*}{$\begin{array}{l}\text { Blank } \\
\text { sample }\end{array}$} & & $\begin{array}{l}\text { Breaking } \\
\text { strength } \\
(\mathrm{MPa})\end{array}$ & $\begin{array}{l}\text { Compressive } \\
\text { strength } \\
\text { (MPa) }\end{array}$ & $\begin{array}{l}\text { Band-pr } \\
\text { ess ratio }\end{array}$ & $\begin{array}{l}\text { Breaking } \\
\text { strength } \\
\text { (MPa) }\end{array}$ & $\begin{array}{l}\text { Compressive } \\
\text { strength (MPa) }\end{array}$ & $\begin{array}{c}\text { Band-p } \\
\text { ress } \\
\text { ratio }\end{array}$ \\
\hline & 0 & 7.2 & 35.1 & 0.21 & 10.9 & 54.5 & 0.20 \\
\hline \multirow{2}{*}{ SD623 } & 10 & 8.3 & 27.5 & 0.30 & 12.5 & 44.1 & 0.28 \\
\hline & 20 & 9.1 & 25.2 & 0.36 & 14.2 & 40.2 & 0.35 \\
\hline \multirow{2}{*}{ PS608 } & 10 & 7.9 & 28.3 & 0.28 & 11.1 & 47.5 & 0.23 \\
\hline & 20 & 8.6 & 27.7 & 0.31 & 13.4 & 45.9 & 0.29 \\
\hline \multirow{2}{*}{ S400 } & 10 & 4.7 & 15.8 & 0.30 & 7.1 & 29.4 & 0.24 \\
\hline & 20 & 5.1 & 14.6 & 0.35 & 8.2 & 27.1 & 0.30 \\
\hline
\end{tabular}

\section{Conclusions}

(1) The water-reducing effect of these three kinds of different content of the emulsion, as shown in Fig.3. It can been seen that different type and different amount of the polymer emulsion have different effect of water-reducing. It can been found that the effect of SD623 to reduce the water is best, whereas S400 is worst.

(2) It shows that polymer emulsion can better improve the barrier properties of cement mortar.

(3) Adding the polymer emulsion can better improve the ratio of bending-compressive strength, thereby increasing its flexibility, and the best of the effect are SD623.

In summary, through the research of how SD623, PS608 and S400 influence the relevant physical and chemical properties of cement-based materials, it can been found that SD623 can better improve the performance of the water-reducing and impermeability of cement.

\section{Acknowledgements}

This work was financially supported by the National Natural Science Fund (51402226) and Hubei province transportation science and technology project (20130113).

\section{References}

[1] Wang Qing, Ding Zhao Yang, Zhang J,Qui L G,Sui Zhi Tong. Study on slag-based geopolymer hydration process[J]. Key Engineering Materials (2011)477:67-71

[2] Davidovits J. Geopolymer chemistry and application [M]. Geopolymer Institute, SaintQuentin, France, 2008:3-15

[3] Van Jarsveld J G S, Van Deventer J S J, Lukey G C. The effect of composition and temperature on the properties of fly ash and kaolinite-based geopolymers[J]. Chemical Engineering Journa,l 2002, 89:63 73.

[4] J.C.Swanepoel, C.A.Strydom.Utilisation of fly ash in a geopolymeric material[J]. Applied Geochemistry, 2002, 17(8):1143-1148.

[5] Sullivan A,Hill R.G,Inexpensive glass polyalkenoate cement based on waste gasifier slag[J]. Morella2011 Proceedings of the European Union thematic PROGRES Worshop,Morella June 2011,Spain,361-368. 